\title{
Impacts of Recurrent Selection and Synthetic Population on Forage and Seed Yields of Monocut Egyptian Clover (Trifolium alexandrinum L.)
}

"Bakheit, B. R. ${ }^{1}$; A. Abo-Elwafa ${ }^{1}$; M.M. Abdel-Galil' and A.M.A. Abdelmonem ${ }^{2}$

${ }^{1}$ Department of Agronomy, Faculty of Agriculture, Assiut University, Assiut, Egypt.

${ }^{2}$ Forage Crops Res. Dept., Field Crops Res. Inst., ARC, Giza, Egypt.

*Corresponding author: Email: bahy@aun.edu.eg

Received on: 18/2/2016

Accepted for publication on: 1/3/2016

\section{Abstract}

The objectives of the current investigation were to determine the response of forage and seed yields and their components in monocut Egyptian clover to two methods of breeding, namely recurrent selection and synthetic population approach. One cycle of recurrent selection among superior accessions was imposed on a base population. Both yields were compared to the base population and a commercial cultivar (c.v. Fahl). In addition, first generation of a synthetic population created by compositing six superior accessions was compared to the commercial cultivar and their parents.

The realized gains of the recurrent selections were 18.6, 11.7, 14.6 and $24.1 \%$ for leaf/stem ratio, fresh, dry and forage protein yields, respectively, over the base population. Moreover, the realized gains were 14.4, 19.2, 13.1 and $16.9 \%$ for number of inflorescences/plant, number of seeds/inflorescence, seed yield and 1000-seed weight, respectively, over the base population.

The first generation of the synthetic population showed increases over parental means of 3.5, 3.0, 4.9 and 3.8\% for leaf/stem ratio, fresh, dry, and forage protein yields, respectively. Similarly, the realized gains were 5.0, 5.3, 3.1 and $4.3 \%$ for number of inflorescences/plant, number of seeds/inflorescence, seed yield and 1000 seed weight, respectively, over to the check cultivar (c.v. Fahl).

Keywords: Recurrent selection, Synthetic population, Monocut Egyptian clover, Forage and seed yield, G.C.V. \& P.C.V., Heritability 


\section{Introduction}

Egyptian clover cv. Fahl is an annual legume, well adapted to the climate of the Mediterranean, Central Europe, India and Southern U.S.A., it is grown for soiling, hay production and grazing. This single cut cultivar is characterized by the rapid growth and large forage yield; hence, it is grown as a cash crop before sowing early summer crops such as cotton. Limited efforts has been done to improve yield potential of monocut Egyptian clover through recurrent selection or synthetic populations in contrast to the multicut Egyptian clover, where early breeders, e.g. AbouEl-Shawareb (1971), applied recurrent selection and reported that selections outyielded the original population by 19.9 to $29.0 \%$ in forage yield, while, Koraiem et al. (1980) reported that recurrent selection was effective in improving forage yield. Bakheit (1989a) found the realized gains were 14.0 and $22.9 \%$ over the base population for forage protein yield in the first and second cycle of recurrent selection, respectively. Rajab (2010) assessed the response to selection among and within berseem ecotypes based on dry forage yield and found that the relative increase over the check average of 13.7-23.5\%. Moreover, Badawy (2013) noted that the realized gain in seed yield due to $\mathrm{S}_{1}$ family selection reached $29.4 \%$ relative to the base population.

Synthetic populations of forage crops may be developed by combining either genotype or plants into a composite strain. Which is a commonly used procedure in forage crops breeding. Radwan et al. (1983) produced a synthetic variety by selecting
13 superior farmer lots with good combining ability and established crossing among them. The highest actual gain of selection recorded 13.1 and $19.2 \%$ in first and second cycles of selection, respectively. The synthetic $\mathrm{F}_{2}$ population increased by $21.3 \%$ in dry forage yield (Bakheit, 1989a). Abdel-Galil et al. (2008) showed that synthetic population had higher yield and yield components than the best parents.

The objectives of the current investigation were to: (1) study the effectiveness of recurrent selection in improving forage and seed yields of the superior accessions of farmers' seed lots of the monocut Egyptian clover genotypes and (2) investigate the effect of synthetic population on the improvement of yielding ability of farmers' seed lots of monocut Egyptian clover.

\section{Materials and Methods \\ Recurrent selection procedure}

The materials used in this study were the best accessions of monocut Egyptian clover among twenty genotypes evaluated in 2010/2011 season at Shandaweel Agricultural Research Station, Sohag, Egypt. A spaced plant nursery of 2000 plants was established in 2011/2012 season where plants were arranged in small guarded plots with five $\mathrm{cm}$ space between plants within rows set at $15 \mathrm{~cm}$. The best yielding 10 percent of the two hundred plants were selected and each plant was caged with fine muslin cloth before blooming followed by applying hand tripping at flowering stage. At maturity time, equal parts of selfed seeds from each of the 200 selected plants were bulked together. 
Selfed seeds were sown in 2012/2013 season in an isolated plot nearby a honeybee-hive which was placed at the time of flowering to allow crosspollination between the selected plants. At harvest, the resulting seeds were bulked together as the new population of the first cycle of recurrent selection. In 2013/2014 season, the first cycle of selection with the original population (base population) and certified seeds from Fahl cultivar were evaluated in two experiments (forage yield traits and seed yield traits) using a randomized complete block design with three replications for each experiment. The plot size for each experiment was one $\mathrm{m}^{2}$. All cultural practices were applied as recommended for Egyptian clover production. Eighty days from sowing, the plots for forage yield were clipped for each population. The traits studied were plant height $(\mathrm{cm})$, leaf/stem ratio, fresh and dry forage yield $\left(\mathrm{kg} / \mathrm{m}^{2}\right)$, forage protein yield $\left(\mathrm{g} / \mathrm{m}^{2}\right)$ and protein percentage which was determined using micro-kjeldahl method as outlined by the A.O.A.C. (1980).

Furthermore, at seed maturity stage, the plots for seed yield traits were harvested. The studied traits were number of inflorescences/plant, number of seeds/inflorescence, seed yield and 1000-seed weight. Data for base population, first cycle of recurrent selection and check cultivar were statistically analyzed according to Gomez and Gomez (1984). The Least significant difference was used for comparisons among populations' averages. The expected mean squares for all traits were found following Miller et al. (1958). The genotypic $\left(\sigma_{\mathrm{g}}^{2}\right)$ and the phenotypic $\left(\sigma_{\mathrm{p}}^{2}\right)$ variances were calculated according to Al-Jibouri et al. (1958). Phenotypic coefficient of variability (P.C.V.) and genotypic coefficient of variability (G.C.V.) were calculated according to Burton (1952).

\section{Synthetic population procedure}

The twenty monocut Egyptian clover accessions that belong to Fahl type were evaluated in 2010/2011 season. The six accessions with the highest yields in open-pollinated progeny test in 2011/2012 season were selected and used as basic material for producing the synthetic variety. Three hundred seeds from each selected accessions were bulked. The composited seeds were planted in isolated plots far from other berseem clover field in 2012/2013 season. All plants were harvested and the seeds were bulked together to obtained the Syn. $F_{1}$ seed population. In 2013/2014 season the synthetic $F_{1}$, the original six selected accessions (parental materials of the synthetic) in addition to the commercial cultivar Fahl, were evaluated in a randomized complete block design using three replications for forage yield characters and three other replications for seed yield characters. Plot size, culture practices, recorded characters and statistical analysis were as described previously for recurrent selection procedure. The predicted response from selecting of the best $5 \%$ plants was calculated using the formula adopted by Falconer (1989) as follows $\Delta \mathrm{G}=\mathrm{i} . \sigma_{\mathrm{p}} \cdot \mathrm{H}$. The percentage of predicted genetic advance was calculated as ${ }_{\mathrm{G}} \%=\frac{\Delta \mathrm{G}}{\overline{\mathrm{X}}} \times 100$.

\section{Results and Discussion}




\section{Performance of recurrent selection population}

The analysis of variances of forage and seed yields and their components showed significant differences among populations for plant height, leaf/stem ratio, fresh and dry forage yields, number of inflorescences / plant, number of seeds/inflorescence, seed yield. Meanwhile, forage protein yield and 1000-seed weight showed highly significant differences among populations (Table 1) revealing the large variability correlated to these characters. Means of one cycle of recurrent selection, their parental accession, check cultivar (c.v. Fahl) and their percentage of the check for all studied traits are presented in Table 2. The increase as a percentage of the population were measured for leaf/ stem ratio (18.6 and 42.1) and for fresh forage yield (11.7 and 29.9), for dry forage yield (14.6 and 44.7), forage protein yield (24.1 and 77.4), number of inflorescences/plant (14.4 and 25.8), number of seeds/inflorescence (19.2 and 26.6), seed yield (13.1 and 23.0) and 1000-seed weight (16.9 and $28.8 \%$ ) in the recurrent selection population over the base population and check cultivar, respectively (Table 2). Such responses indicate effectiveness of this methods of selection.

Comparison between the check cultivar and selections of the first cycle of recurrent selection indicated that a considerable improvement has been achieved for all studied traits. Meanwhile, the recurrent selection population significantly increased over the base population for plant height, forage protein yield, number of seeds/inflorescence, seed yield and 1000-seed weight. These results are in line with those reported by AbouEl-Shawareb (1971), Koraiem et al. (1980), Bakheit (1989a\&b). Mikhiel (1987), Ahmed (1992), Ahmed (2006), Rajab (2010) and Badawy (2013) who found that recurrent selection was effective in improving yield in multi-cut Egyptian clover. In an early study, Johnson et al. (1955) phenotype recurrent selection was suggested as effective means for modifying an unselected population of sweet clover to improve uniformity in growth type and plant vigor.

The phenotypic variance $\left(\sigma_{\mathrm{p}}^{2}\right)$ and genotypic variances $\left(\sigma_{\mathrm{g}}^{2}\right)$, P.C.V. and G.C.V. for the three populations are presented in Table 3 . The percentage of genotypic to phenotypic variances $\left(\sigma_{\mathrm{g}}^{2}-\sigma_{\mathrm{p}}^{2}\right)$ were high for all traits indicating that they are highly heritable. Moreover, the phenotypic and genotypic coefficient of variation ranged from 5.4 and $5.0 \%$ for plant height to 27.6 and $27.2 \%$ for forage protein yield, referring to enough variation a following future selection.

\section{Performance of synthetic popula- tion}

The analysis of variance of forage and seed yields and their components showed that the eight populations (synthetic, their 6 parents and the check cultivar) differed significantly or highly significantly for all traits (Table 4). The obtained results revealed significant differences among populations. Means of forage and seed yields and their components of the synthetic population, their parents, and check cultivar (c.v. Fahl) and their percentage of the check, are presented in Tables 5 and 6 . The re- 
sults revealed realized gains for plant height (6.0 and 2.5), leaf/stem ratio (15.2 and 3.2), fresh forage yield (13.1 and 2.7), dry forage yield (20.4 and 4.2) and forage protein yield (23.0 and $3.1 \%$ ) in synthetic population over the check cultivar and parental mean, respectively (Table 5). Results in Table 6 showed realized gains for number of inflorescences/plant (13.3 and 4.4), number of seeds/inflorescence (16.7 and 4.7), seed yield (15.7 and 2.8) and 1000seed weight (14.3 and 3.9\%) in synthetic population over the check cultivar and parental mean, respectively.

The results means of the synthetic population significantly exceeded those of the check cultivar for all traits. On the other hand, there were no significant differences between the parental mean and the synthetic population for all traits. In addition, the comparison showed that most parents were significantly different from check variety in all traits. The higher forage and seed yields and their components of the synthetic population relative to the check cultivar could be due to the higher yield and combining ability of most the parents involved in the production of the synthetic population. The synthetic productivity exceeded that of the check cultivar in all traits. Moreover, this synthetic would be adapted to a wider range of environmental factors due to the presence of genetic variability and would be more stable from season to season. In addition to this synthetic population could be used as reservoir of desirable gene combinations. These results are in line with those obtained by Katta et al. (1980), Bakheit (1989a), Abdel-
Galil et al. (2008) and Badawy (2013) who found that the synthetic population was effective in improving yield in multi-cut Egyptian clover.

The phenotypic $\left(\sigma_{\mathrm{p}}^{2}\right)$ and genotypic $\left(\sigma_{\mathrm{g}}^{2}\right)$ variances, P.C.V. and G.C.V., heritability $\%$ and expected response estimates for the eight populations are presented in Table 7. The genotypic variance relative to the environmental variance was high for all traits. The environmental variation ranged from 9.6 for leaf/stem ratio to $38.1 \%$ for 1000 -seed weight.

The phenotypic and genotypic coefficient of variation ranged from 3.10 and $2.45 \%$ for plant height to 12.36 and $11.55 \%$ for forage protein yield. These results were reflected in lower estimates for broad sense heritability of plant height as compared to forage protein yield. The expected responses ranged from 4.1 for plant height to $22.24 \%$ for forage protein yield.

Finally, the used methods proved to be power full tool for improving the forage and seed yield as well as their components in the studied materials. Consequently, these methods may be applied in other materials of monocut Egyptian clover.

\section{References}

Abdel-Galil, M.M., A.A. Helmy \& N.M. Hamed. 2008. Developing a synthetic population through selection in Egyptian clover genotypes (Trifolium alexandrinum L.). J. Agric. Sci. Mansoura Univ., 33 (2): 983-989.

Abou-El-Shawareb, O. 1971. Comparative efficiency of mass and recurrent selection breeding methods in the improvement of Egyptian "Berseem" (Trifolium 
alexandrinum L.). Ph.D. Thesis, Fac. Agric., Cairo Univ., Egypt.

Ahmed, M. A. 1992. Improvement of berseem clover (Trifolium alexandrinum L.) by different methods of selection. Ph.D. Thesis, Fac. Agric., Alex Univ., Egypt.

Ahmed, M. A. 2006. Response to three methods of recurrent selection in a khadarawi berseem (Trifolium alexandrinum L.) population. Alex. J. Agric. Res., 51 (3): 13-23.

Al-Jibouri, H.A., P.A. Miller \& H.F. Robinson. 1958. Genotypic and environmental variances and covariances in an upland cotton cross of interspecific origin. Agron. J. 50: 633-636.

A.O.A.C. 1980. Official Methods of Analysis, Association of Official Agricultural Chemists, $13^{\text {th }}$ ed. A.O.A.C., Washington, D.C.

Badawy, A.S.M. 2013. Recurrent selection for seed yield in "Helaly" Berseem clover. Ph.D. Thesis, Fac. Agric., Alex. Univ., Egypt.

Bakheit, B.R. 1989a. The effect of recurrent selection and performance of seed synthetics in berseem clover (Trifolium alexandrinum L.). Assiut J. Agric. Sci., 20 (1): 189-198.

Bakheit, B.R. 1989b. Selection for seed yield production of Egyptian clover (Trifolium alexandrinum L.) c.v. Fahl. Plant Breeding, 103: 278-285.

Burton, G.W. 1952. Quantitative inheritance in grasses. Proc. $6^{\text {th }}$ Int. Grassland Congr., 1: 277283.

Falconer, D.S. 1989. Introduction to Quantitative Genetics. $3^{\text {rd }}$ Ed. Longman Scientific and Technical, New York, Pages: 438.
Gomez, K.A. \& A.A. Gomez 1984. Statistical Procedures for Agricultural Research, $2^{\text {nd }}$ Ed. Wily, New York.

Johanson, H.W., H.F. Robinson \& R.E. Comstock. 1955. Estimates of genetic and environmental variability in Soybeans. Agron. J. 47: 314-318.

Katta, Y.S., N.S. El-Keredy \& F.M. Ali. 1980. Estimation of combining ability in relation to polycross test in berseem clover (Trifolium alexandrinum L.). Egypt. J. Genet. Cytol. 9: 99105.

Koraiem, Y.S., M.M. Habib, M.M. El-Rouby \& M.T.H. Hassan. 1980. Selection in berseem clover (Trifolium alexandrinum L.). Alex. J. Agric. Res., 28: 455-462.

Mikhiel, G.S. 1987. Studies on forage crops improvements. Ph.D. Thesis, Fac. of Agric., Alex. Univ., Egypt.

Miller, P.A., J.C. Williams, H.F. Robinson \& R.E. Comstocm. 1958. Estimates of genotypic and environmental variance and covariances in Upland cotton and their implications in selection. Agron. J. 80: 126-131.

Radwan, M.S., R. Shabana, A.M. Rammah \& M.A. El-Nehrawi. 1983. Variability and combining ability estimates in farmers seeds lots of Egyptian clover (Trifolium alexandrinum) L.). $1^{\text {st }}$ Hon. Con. Agric. Bot. Sci., 27-28 April, 1983, 86-105.

Rajab, M.N. 2010. Studies on breeding of Egyptian clover (Trifolium alexandrinum) L.). Ph.D. Thesis, Fac. Agric., Minia Univ., Egypt. 
Table 1. Analysis of variance of forage and seed yields and their components for the one cycle of recurrent selection and their base population and check cultivar in monocut Egyptian clover.

\begin{tabular}{|c|c|c|c|c|c|c|c|c|}
\hline \multirow{3}{*}{$\begin{array}{c}\text { Source of } \\
\text { variations }\end{array}$} & \multirow[b]{3}{*}{ d.f } & \multicolumn{7}{|c|}{ Mean squares } \\
\hline & & \multicolumn{7}{|c|}{ Forage characters } \\
\hline & & $\begin{array}{c}\text { Plant } \\
\text { height }(\mathrm{cm})\end{array}$ & & $\begin{array}{l}\text { af/stem } \\
\text { tio }(\%)\end{array}$ & \multicolumn{2}{|c|}{$\begin{array}{c}\text { Fresh for- } \\
\text { age yield } \\
\left(\mathbf{k g} / \mathbf{m}^{2}\right)\end{array}$} & $\begin{array}{c}\text { Dry forage } \\
\text { yield } \\
\left(\mathbf{k g} / \mathbf{m}^{2}\right)\end{array}$ & $\begin{array}{c}\text { Forage pro- } \\
\text { tein yield } \\
\left(\mathrm{kg} / \mathrm{m}^{2}\right)\end{array}$ \\
\hline Replications & 2 & 7.75 & & 1.56 & \multicolumn{2}{|c|}{0.021} & 1.06 & 379.0 \\
\hline Populations & 2 & $68.79 *$ & & $107.6^{*}$ & \multicolumn{2}{|c|}{$2.000 *$} & 0.157 & $7200.9 * *$ \\
\hline \multirow[t]{3}{*}{ Error } & 4 & 9.79 & & 11.35 & 0.1 & 63 & 0.024 & 179.6 \\
\hline & & \multicolumn{7}{|c|}{ Seed characters } \\
\hline & & \multicolumn{2}{|c|}{$\begin{array}{c}\text { Number of in- } \\
\text { flores- } \\
\text { cences/plant }\end{array}$} & \multicolumn{2}{|c|}{$\begin{array}{c}\text { Number of } \\
\text { seeds/ inflores- } \\
\text { cence }\end{array}$} & \multicolumn{2}{|c|}{$\begin{array}{c}\text { Seed yield } / \mathrm{m}^{2} \\
\text { (g) }\end{array}$} & $\begin{array}{l}\text { 1000-seed } \\
\text { weight } \\
\text { (g) }\end{array}$ \\
\hline Replications & 2 & \multicolumn{2}{|l|}{0.229} & \multicolumn{2}{|c|}{1.482} & \multicolumn{2}{|r|}{7.00} & 0.40 \\
\hline Populations & 2 & \multicolumn{2}{|l|}{7.238} & \multicolumn{2}{|c|}{$93.11 *$} & \multicolumn{2}{|c|}{$490.33 *$} & $0.882 * *$ \\
\hline Error & 4 & \multicolumn{2}{|l|}{1.090} & \multicolumn{2}{|c|}{10.785} & \multicolumn{2}{|c|}{30.83} & 0.031 \\
\hline
\end{tabular}

* and ** significant at the 0.05 and 0.01 levels of probability, respectively. 
Table 2. Means of forage and seed yields and their components of the one cycle of recurrent selection, their parental accessions, and check cultivar and their percentage of the check cultivar in monocut Egyptian clover.

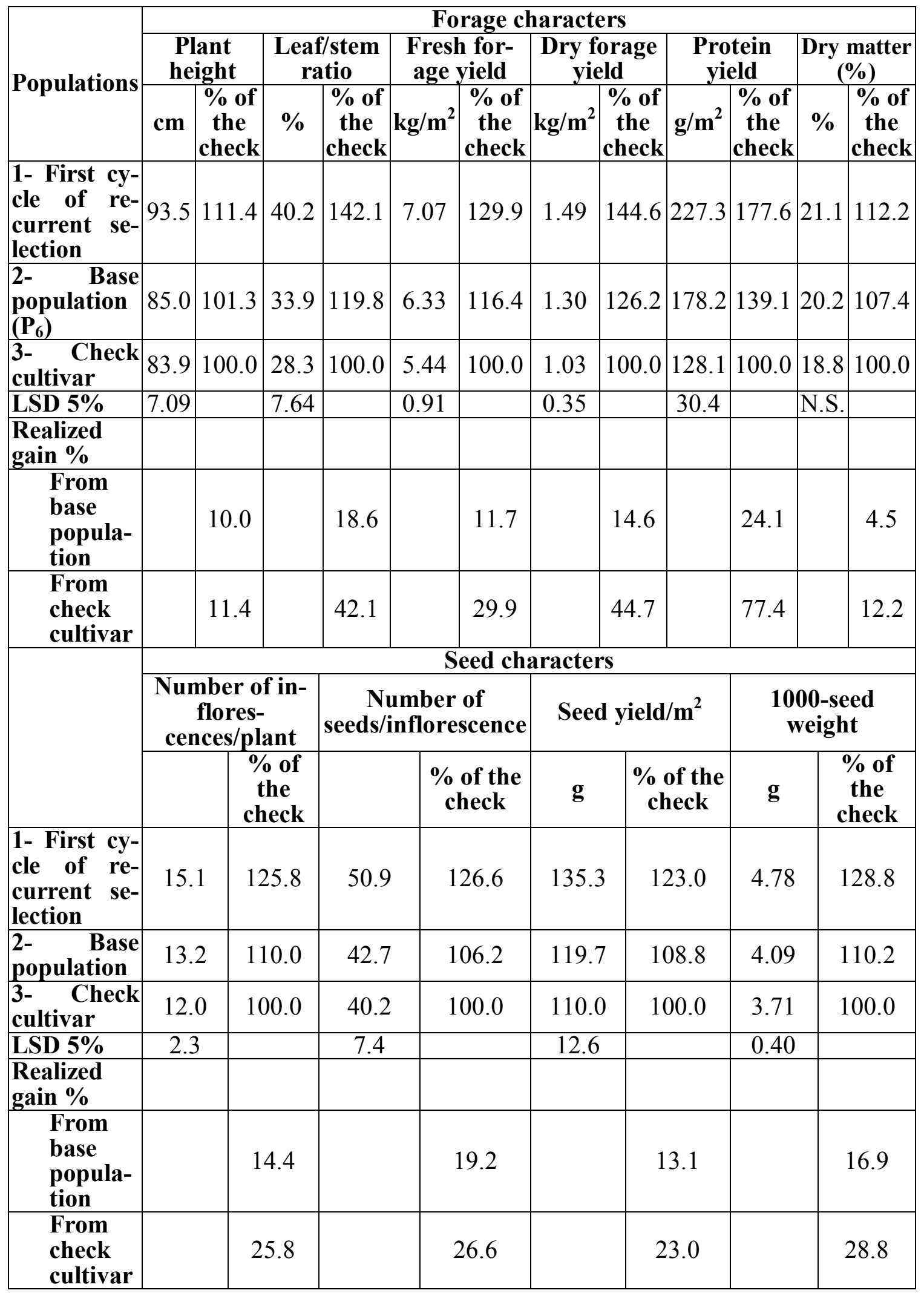


Table 3. Phenotypic ( $\left.\sigma_{\mathrm{p}}^{2}\right)$, genotypic $\left(\sigma_{\mathrm{g}}^{2}\right)$ variances, phenotypic (P.C.V.), and genotypic (G.C.V.) coefficient of variations and heritability \% $\left(h^{2}\right)$, for forage yields and their components in one cycle of recurrent selection and their base population and check cultivar in monocut Egyptian clover.

\begin{tabular}{|c|c|c|c|c|c|c|c|}
\hline \multirow[b]{2}{*}{ Estimates } & \multicolumn{7}{|c|}{ Forage characters } \\
\hline & $\begin{array}{c}\text { Plant } \\
\text { height }(\mathrm{cm})\end{array}$ & & $\begin{array}{l}\text { eaf/stem } \\
\text { atio }(\%)\end{array}$ & \multicolumn{2}{|c|}{$\begin{array}{l}\text { Fresh for- } \\
\text { age yield } \\
\left(\mathrm{kg} / \mathbf{m}^{2}\right) \\
\end{array}$} & $\begin{array}{c}\text { Dry forage } \\
\text { yield } \\
\left(\mathrm{kg} / \mathbf{m}^{2}\right) \\
\end{array}$ & $\begin{array}{c}\text { Protein } \\
\text { yield } \\
\left(\mathrm{gm} / \mathrm{m}^{2}\right)\end{array}$ \\
\hline$\sigma_{p}^{2}$ & 22.93 & & 35.9 & \multicolumn{2}{|c|}{0.67} & 0.052 & 2400.3 \\
\hline$\sigma_{g}^{2}$ & 19.67 & & 32.1 & \multicolumn{2}{|c|}{0.61} & 0.044 & 2340.4 \\
\hline P.C.V. (\%) & 5.4 & & 17.6 & \multicolumn{2}{|c|}{13.03} & 17.9 & 27.55 \\
\hline G.C.V. (\%) & 5.0 & & 16.6 & \multicolumn{2}{|c|}{12.44} & 16.48 & 27.2 \\
\hline \multirow[t]{3}{*}{$h^{2}(\%)$} & 85.7 & & 89.4 & & & 84.6 & 97.5 \\
\hline & \multicolumn{7}{|c|}{ Seed characters } \\
\hline & \multicolumn{2}{|c|}{$\begin{array}{c}\text { Number of in- } \\
\text { florescences/ } \\
\text { plant }\end{array}$} & \multicolumn{2}{|c|}{$\begin{array}{c}\text { Number of } \\
\text { seeds/ inflores- } \\
\text { cence }\end{array}$} & \multicolumn{2}{|c|}{$\underset{(\mathrm{g})}{\text { Seed }}$ yield $/ \mathbf{m}^{2}$} & $\begin{array}{l}\text { 1000-seed } \\
\text { weight } \\
\text { (g) }\end{array}$ \\
\hline$\sigma_{p}^{2}$ & \multicolumn{2}{|l|}{2.41} & \multicolumn{2}{|c|}{31.0} & \multicolumn{2}{|c|}{163.4} & 0.294 \\
\hline$\sigma_{g}^{2}$ & \multicolumn{2}{|l|}{2.05} & \multicolumn{2}{|c|}{27.4} & \multicolumn{2}{|c|}{153.2} & 0.283 \\
\hline P.C.V. (\%) & \multicolumn{2}{|l|}{11.6} & \multicolumn{2}{|c|}{12.5} & \multicolumn{2}{|r|}{10.51} & 12.9 \\
\hline G.C.V. (\%) & \multicolumn{2}{|l|}{10.7} & \multicolumn{2}{|c|}{11.7} & \multicolumn{2}{|c|}{10.17} & 12.7 \\
\hline$h^{2}(\%)$ & \multicolumn{2}{|l|}{85.0} & \multicolumn{2}{|c|}{88.4} & \multicolumn{2}{|r|}{93.7} & 96.2 \\
\hline
\end{tabular}


Table 4. Analysis of variance of forage and seed yields and their components for the synthetic, their six parental accessions and check cultivar in monocut Egyptian clover.

\begin{tabular}{|c|c|c|c|c|c|c|c|}
\hline \multirow{3}{*}{$\begin{array}{c}\text { Source of } \\
\text { variations }\end{array}$} & \multirow[b]{3}{*}{ d.f } & \multicolumn{6}{|c|}{ Mean squares } \\
\hline & & \multicolumn{6}{|c|}{ Forage characters } \\
\hline & & $\begin{array}{c}\text { Plant } \\
\text { height }(\mathrm{cm})\end{array}$ & $\begin{array}{l}\text { Leaf/stem } \\
\text { ratio (\%) }\end{array}$ & \multicolumn{2}{|c|}{$\begin{array}{l}\text { Fresh for- } \\
\text { age yield } \\
\left(\mathrm{kg} / \mathrm{m}^{2}\right)\end{array}$} & $\begin{array}{c}\text { Dry forage } \\
\text { yield } \\
\left(\mathrm{kg} / \mathrm{m}^{2}\right)\end{array}$ & $\begin{array}{c}\text { Protein } \\
\text { yield }\left(\mathrm{g} / \mathrm{m}^{2}\right)\end{array}$ \\
\hline Replications & 2 & 1.296 & 0.73 & \multicolumn{2}{|c|}{0.207} & 0.157 & 122.3 \\
\hline Populations & 7 & $20.85^{*}$ & $11.672 * *$ & \multicolumn{2}{|c|}{$0.340^{*}$} & $0.030^{*}$ & $1039.1^{* *}$ \\
\hline Error & 14 & 7.38 & 1.122 & \multicolumn{2}{|c|}{0.11} & 0.009 & 131.4 \\
\hline & & \multicolumn{6}{|c|}{ Seed characters } \\
\hline & & $\begin{array}{c}\text { Number of in- } \\
\text { florescences/ } \\
\text { plant }\end{array}$ & \multicolumn{2}{|c|}{$\begin{array}{c}\text { Number of } \\
\text { seeds/ inflores- } \\
\text { cence }\end{array}$} & \multicolumn{2}{|c|}{$\begin{array}{c}\text { Seed yield } / \mathrm{m}^{2} \\
(\mathrm{~g})\end{array}$} & $\begin{array}{c}\text { 1000-seed } \\
\text { weight } \\
\text { (g) }\end{array}$ \\
\hline Replications & 2 & 0.14 & \multicolumn{2}{|c|}{13.82} & \multicolumn{2}{|c|}{40.87} & 0.173 \\
\hline Populations & 7 & $1.36^{*}$ & \multicolumn{2}{|c|}{$29.05^{*}$} & \multicolumn{2}{|c|}{$159.14 * *$} & $0.210^{*}$ \\
\hline Error & 14 & 0.356 & \multicolumn{2}{|c|}{9.59} & \multicolumn{2}{|c|}{29.02} & 0.08 \\
\hline
\end{tabular}


Table 5. Means of forage yield and their components of the synthetic, their parental accessions, and check cultivar and their percentage of the check cultivar in monocut Egyptian clover.

\begin{tabular}{|c|c|c|c|c|c|c|c|c|c|c|}
\hline \multirow[b]{2}{*}{ Populations } & \multicolumn{2}{|c|}{ Plant height } & \multicolumn{2}{|c|}{$\begin{array}{c}\text { Leaf/stem } \\
\text { ratio }\end{array}$} & \multicolumn{2}{|c|}{\begin{tabular}{|c|}
$\begin{array}{c}\text { Fresh forage } \\
\text { yield }\end{array}$ \\
\end{tabular}} & \multicolumn{2}{|c|}{$\begin{array}{c}\text { Dry forage } \\
\text { yield }\end{array}$} & \multicolumn{2}{|c|}{$\begin{array}{c}\text { Forage pro- } \\
\text { tein yield }\end{array}$} \\
\hline & cm & $\begin{array}{c}\% \text { of } \\
\text { the } \\
\text { check }\end{array}$ & $\%$ & $\begin{array}{c}\text { \% of } \\
\text { the } \\
\text { check }\end{array}$ & $\mathrm{Kg} / \mathrm{m}^{2}$ & \begin{tabular}{|c} 
\% of \\
the \\
check
\end{tabular} & $\mathrm{Kg} / \mathrm{m}^{2}$ & $\begin{array}{c}\text { \% of } \\
\text { the } \\
\text { check }\end{array}$ & $\mathrm{g} / \mathrm{m}^{2}$ & $\begin{array}{c}\text { \% of } \\
\text { the } \\
\text { check }\end{array}$ \\
\hline $\mathbf{P}_{3}$ & 89.1 & 106.2 & 32.2 & 113.8 & 6.10 & 112.1 & 1.22 & 118.4 & 181.7 & 137.6 \\
\hline $\mathbf{P}_{6}$ & 84.0 & 100.1 & 33.9 & 115.8 & 6.33 & 116.4 & 1.30 & 126.2 & 180.8 & 137.0 \\
\hline $\mathbf{P}_{11}$ & 86.1 & 102.6 & 30.0 & 106.0 & 5.66 & 104.0 & 1.11 & 107.8 & 147.7 & 111.9 \\
\hline $\mathbf{P}_{13}$ & 83.2 & 99.2 & 29.2 & 103.2 & 5.57 & 102.4 & 1.03 & 100.0 & 135.5 & 102.7 \\
\hline $\mathbf{P}_{15}$ & 88.9 & 106.0 & 31.6 & 111.7 & 6.06 & 111.4 & 1.19 & 115.5 & 156.9 & 118.9 \\
\hline$P_{19}$ & 89.2 & 106.3 & 32.9 & 116.3 & 6.23 & 114.5 & 1.27 & 123.3 & 163.0 & 123.5 \\
\hline $\begin{array}{l}\text { Synthetic } \\
\text { population }\end{array}$ & 88.9 & 106.0 & 32.6 & 115.2 & 6.15 & 113.1 & 1.24 & 120.4 & 162.4 & 123.0 \\
\hline $\begin{array}{l}\text { Check culti- } \\
\text { var }\end{array}$ & 83.9 & 100.0 & 28.3 & 100.0 & 5.44 & 100.0 & 1.03 & 100.0 & 132.0 & 100.0 \\
\hline Parents mean & 86.7 & 103.3 & 31.6 & 111.7 & 5.99 & 110.1 & 1.19 & 115.5 & 157.4 & 119.2 \\
\hline LSD 5\% & 4.8 & & 1.85 & & 0.58 & & 0.17 & & 20.1 & \\
\hline \multicolumn{11}{|l|}{$\begin{array}{l}\text { Realized gain } \\
\%\end{array}$} \\
\hline $\begin{array}{l}\text { From } \\
\text { check }\end{array}$ & & 6.0 & & 15.2 & & 13.1 & & 20.4 & & 23.0 \\
\hline $\begin{array}{l}\text { From par- } \\
\text { ents mean }\end{array}$ & & 2.5 & & 3.2 & & 2.7 & & 4.2 & & 3.1 \\
\hline
\end{tabular}


Table 6. Means of seed yield and their components of the synthetic, their parental accessions, and check cultivar and their percentage of the check cultivar in monocut Egyptian clover.

\begin{tabular}{|c|c|c|c|c|c|c|c|c|}
\hline \multirow[b]{2}{*}{ Populations } & \multicolumn{2}{|c|}{$\begin{array}{c}\text { Number of inflores- } \\
\text { cences/plant }\end{array}$} & \multicolumn{2}{|c|}{$\begin{array}{c}\text { Number of } \\
\text { seeds/inflorescence }\end{array}$} & \multicolumn{2}{|c|}{$\begin{array}{c}\text { Seed } \\
\text { yield } / \mathbf{m}^{2}\end{array}$} & \multicolumn{2}{|c|}{$\begin{array}{c}\text { 1000-seed } \\
\text { weight }\end{array}$} \\
\hline & g & $\begin{array}{l}\text { \% of the } \\
\text { check }\end{array}$ & g & $\begin{array}{l}\% \text { of the } \\
\text { check }\end{array}$ & g & $\begin{array}{c}\text { \% of } \\
\text { the } \\
\text { check }\end{array}$ & $\mathbf{g}$ & $\begin{array}{l}\text { \% of } \\
\text { the } \\
\text { check }\end{array}$ \\
\hline $\mathbf{P}_{3}$ & 13.0 & 108.3 & 44.0 & 109.4 & 120.7 & 109.7 & 3.98 & 107.6 \\
\hline $\mathbf{P}_{6}$ & 13.2 & 110.0 & 42.7 & 106.2 & 119.7 & 108.8 & 4.09 & 110.5 \\
\hline $\mathbf{P}_{11}$ & 13.7 & 114.2 & 48.8 & 121.4 & 129.3 & 117.6 & 4.44 & 120.0 \\
\hline $\mathbf{P}_{13}$ & 13.6 & 113.3 & 48.2 & 119.9 & 131.0 & 119.1 & 4.28 & 115.7 \\
\hline $\mathbf{P}_{15}$ & 12.4 & 103.3 & 43.1 & 107.2 & 126.3 & 114.8 & 3.87 & 104.6 \\
\hline$P_{19}$ & 12.2 & 101.7 & 42.1 & 104.7 & 115.7 & 105.2 & 3.74 & 101.1 \\
\hline Synthetic & 13.6 & 113.3 & 46.9 & 116.7 & 127.3 & 115.7 & 4.23 & 114.3 \\
\hline Check cultivar & 12.0 & 100.0 & 40.2 & 100.0 & 110.0 & 100.0 & 3.70 & 100.0 \\
\hline Parents mean & 13.0 & 108.3 & 44.8 & 111.4 & 123.8 & 112.6 & 4.07 & 110.0 \\
\hline LSD 5\% & 1.05 & & 5.4 & & 9.4 & & 0.5 & \\
\hline \multicolumn{9}{|l|}{$\begin{array}{l}\text { Realized gain } \\
\%\end{array}$} \\
\hline $\begin{array}{l}\text { From } \\
\text { check }\end{array}$ & & 13.3 & & 16.7 & & 15.7 & & 14.3 \\
\hline $\begin{array}{l}\text { From par- } \\
\text { ents mean }\end{array}$ & & 4.6 & & 4.7 & & 2.8 & & 3.9 \\
\hline
\end{tabular}


Table 7. Phenotypic $\left(\sigma_{\mathrm{p}}^{2}\right)$ and genotypic $\left(\sigma_{\mathrm{g}}^{2}\right)$ variances, phenotypic (P.C.V.) and genotypic (G.C.V.) coefficient variations, heritability $\left(h^{2}\right)$, and expected response for forage and seed yields and their components in synthetic and their parental accessions and check cultivar of the monocut Egyptian clover.

\begin{tabular}{|c|c|c|c|c|c|c|c|}
\hline \multirow[b]{2}{*}{ Estimates } & \multicolumn{7}{|c|}{ Forage characters } \\
\hline & $\begin{array}{c}\text { Plant } \\
\text { height }(\mathrm{cm})\end{array}$ & \multicolumn{2}{|c|}{$\begin{array}{l}\text { Leaf/stem } \\
\text { ratio }(\%)\end{array}$} & \multicolumn{2}{|c|}{$\begin{array}{l}\text { Fresh for- } \\
\text { age yield } \\
\left(\mathrm{kg} / \mathbf{m}^{2}\right)\end{array}$} & \begin{tabular}{|c|} 
Dry forage \\
yield \\
$\left(\mathbf{k g} / \mathbf{m}^{2}\right)$
\end{tabular} & $\begin{array}{c}\text { Protein } \\
\text { yield }\left(\mathrm{g} / \mathrm{m}^{2}\right)\end{array}$ \\
\hline$\sigma_{p}^{2}$ & 6.95 & \multicolumn{2}{|c|}{3.89} & \multicolumn{2}{|c|}{0.113} & 0.01 & 346.4 \\
\hline$\sigma_{g}^{2}$ & 4.49 & \multicolumn{2}{|c|}{3.52} & \multicolumn{2}{|c|}{0.077} & 0.007 & 302.6 \\
\hline P.C.V. (\%) & 3.10 & \multicolumn{2}{|c|}{6.40} & \multicolumn{2}{|c|}{5.74} & 8.70 & 12.36 \\
\hline G.C.V. (\%) & 2.45 & \multicolumn{2}{|c|}{6.09} & \multicolumn{2}{|c|}{4.73} & 7.28 & 11.55 \\
\hline$h^{2}(\%)$ & 64.6 & \multicolumn{2}{|c|}{90.4} & \multicolumn{2}{|c|}{67.9} & 70.0 & 87.3 \\
\hline $\begin{array}{l}\text { Expected re- } \\
\text { sponse }\end{array}$ & 3.51 & \multicolumn{2}{|c|}{3.68} & \multicolumn{2}{|c|}{0.47} & 0.144 & 33.5 \\
\hline \multirow[t]{3}{*}{$\begin{array}{c}\text { Expected re- } \\
\text { sponse \% } \\
\end{array}$} & 4.1 & \multicolumn{2}{|c|}{11.95} & \multicolumn{2}{|c|}{8.02} & 12.52 & 22.24 \\
\hline & \multicolumn{7}{|c|}{ Seed characters } \\
\hline & \multicolumn{2}{|c|}{$\begin{array}{l}\text { Number of inflo- } \\
\text { rescences plant }\end{array}$} & \multicolumn{2}{|c|}{$\begin{array}{c}\text { Number of } \\
\text { seeds/ inflores- } \\
\text { cence }\end{array}$} & & $\begin{array}{l}\text { d yield } / \mathbf{m}^{2} \\
(\mathrm{~g})\end{array}$ & $\begin{array}{l}\text { 1000-seed } \\
\text { weight } \\
\text { (g) }\end{array}$ \\
\hline$\sigma_{p}^{2}$ & \multicolumn{2}{|l|}{0.453} & \multicolumn{2}{|c|}{9.68} & & 53.1 & 0.070 \\
\hline$\sigma_{g}^{2}$ & \multicolumn{2}{|l|}{0.335} & \multicolumn{2}{|c|}{6.49} & & 43.4 & 0.043 \\
\hline P.C.V. (\%) & \multicolumn{2}{|l|}{5.23} & \multicolumn{2}{|c|}{7.01} & & 6.05 & 6.61 \\
\hline G.C.V. (\%) & \multicolumn{2}{|l|}{4.50} & \multicolumn{2}{|c|}{5.79} & & 5.47 & 5.18 \\
\hline $\mathbf{h}^{2}$ & \multicolumn{2}{|l|}{73.9} & \multicolumn{2}{|c|}{67.1} & & 81.7 & 61.9 \\
\hline $\begin{array}{l}\text { Expected re- } \\
\text { sponse }\end{array}$ & \multicolumn{2}{|l|}{1.03} & \multicolumn{2}{|c|}{4.31} & & 12.28 & 0.34 \\
\hline $\begin{array}{l}\text { Expected re- } \\
\text { sponse \% }\end{array}$ & \multicolumn{2}{|l|}{8.00} & \multicolumn{2}{|c|}{9.80} & & 10.20 & 8.50 \\
\hline
\end{tabular}


تأثير الاتخاب الدوري والعثيرة التركيبية علي المحصول العلفي والبذري في البرسيم

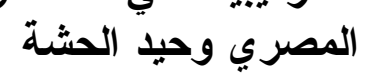

باهي راغب بخيث' ، عاطف أبو الوفا أحمد' ، محي الدين محمد عبد الجليل' ،

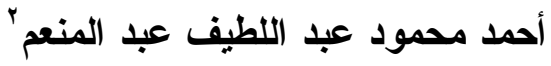

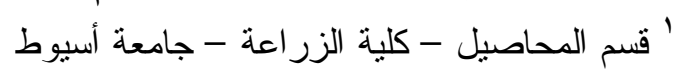

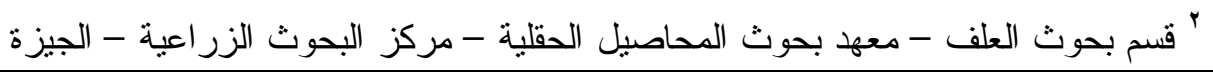

استهدف البحث در اسة تأثير الانتخاب الدوري علي المحصول العلفي و البذري ومكوناتهما في البرسيم المصري وحيد الحشة وكذلك سلوك صنف تركيبي حيث تم إجر اء دورة و احدة مسن الانتخاب الدوري في عثيرة منتخبة. ثم قيمت هذه الدورة لصفات المحصول العلفـي و البــذري

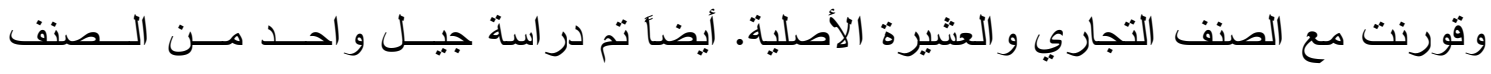
التركيبي تكون من خلط ستة تر اكيب ور اثية منتخبة للمحصول العالي و القدرة الائتلافية العاليــة وقيمة الصفات المحصولية العلفية و البذرية مع مقارنتها بالآباء و الصنف التجاري. وكانت أهم النتائج المتحصل عليها:

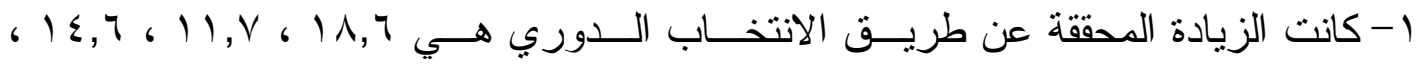

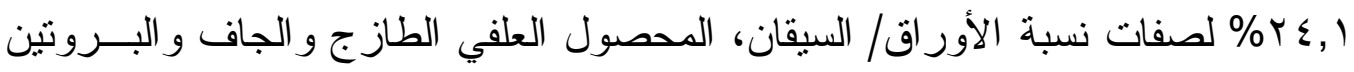
علي التو الي عن منوسط العشيرة الأصلية، أيضأ كانت الزيادة المحققة في هذه الطريقــة

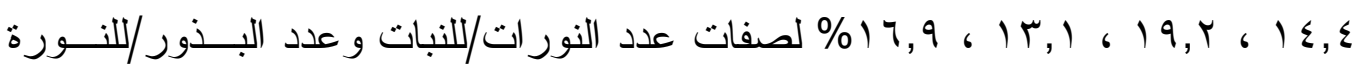
و وحصول البذور ووزن . . 1 بذرة علي التو الي مقارنة بالعثيرة الأصلية. r- تفوق الصنف التركيبي في الجيل الأول التركيبي عن منتسط الآباء بمقدار ه, ، ، ., ،

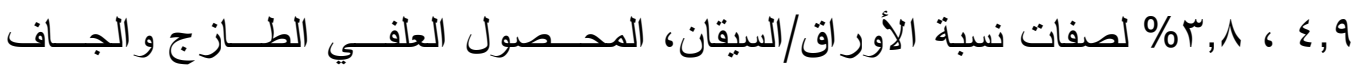
و البروتين علي التو الي كنسبة مئوية من الصنف التجاري، أيضاً كانت الزيادة المحقةــة

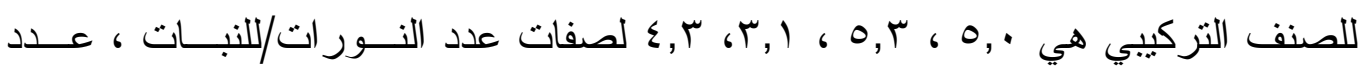
البذور/للانورة، محصول البذور، وزن . . . 1 بذرة علي التو الي. لم تلاحظ ميزة جوهرية للعشيرة التزكيبية بالمقارنة ببعض الآباء وذللك لأن الآباء منتخبـة للمحصول العالي ولكن من ناحية أخري فإن تعدد التز اكيب الور اثية الداخلة فيه ميزة في ثبــات السلوك عبر الظروف البيئية المتباينة مقارنة بأي من آبائه. 